\title{
Serratia proteamaculans (Paine and Stansfield) comb. nov., a Senior Subjective Synonym of Serratia liquefaciens (Grimes and Hennerty) Bascomb et al.
}

\author{
PATRICK A. D. GRIMONT, $\nmid$ FRANCINE GRIMONT, $\dagger$ AND MORTIMER P. STARR \\ Department of Bacteriology, University of California, Davis, California 95616
}

\begin{abstract}
In 1919, Paine and Stansfield attributed a leaf-spot disease of the tropical plant Protea cynaroides to Pseudomonas proteamaculans. This organism, placed at various times in the genera Xanthomonas, Erwinia, and Enterobacter and now known as Erwinia proteamaculans (Paine and Stansfield 1919) Dye 1966, is listed in the first (1976) draft of the Approved List of Bacterial Names. We demonstrate here-on the basis of biochemical properties, polynucleotide sequence relatedness, and pathobiological capacity-the identity of (i) the only strain (ATCC 19323 = Dye ZL1 = ICPB XP176 = NCPPB 245; here designated as the type strain of $P$. proteamaculans) of $E$. proteamaculans still extant from the Paine and Stansfield study with (ii) Serratia liquefaciens biotype C1c. Based on the results of our study, we recommend the transfer of $E$. proteamaculans to the genus Serratia. Serratia proteamaculans (Paine and Stansfield 1919) comb. nov. is to be regarded as a senior subjective synonym of $S$. liquefaciens (Grimes and Hennerty 1931) Bascomb et al. 1971.
\end{abstract}

In 1919, Paine and Stansfield (29) observed in Kew Gardens (London) what they believed to be a leaf-spot disease of the tropical plant Protea cynaroides (vernacular name, King Protea). They attributed the disease to a bacterium which they isolated from the leaf spots and named Pseudomonas proteamaculans (29). Although no bacterial leaf-spot disease of Protea has been reported since 1921 (28), the taxonomic position of the alleged causative agent has changed several times, as evidenced by the following list of objective synonyms: Pseudomonas proteamaculans Paine and Stansfield 1919 (29); Bacterium proteamaculans (Paine and Stansfield 1919) Elliott 1930 (16); Phytomonas proteamaculans (Paine and Stansfield 1919) Bergey et al. 1930 (4); Xanthomonas proteamaculans (Paine and Stansfield 1919) Burkholder 1948 (11); Erwinia proteamaculans (Paine and Stansfield 1919) Dye 1969 (14). In the eighth (1974) edition of Bergey's Manual, Lelliott commented upon Erwinia proteamaculans in the following manner: "Possibly an Enterobacter sp.; excluded from Erwinia because the only known extant cotype produces lipase, and lysine and ornithine decarboxylases" (25).

The taxonomy of plant-pathogenic bacteria has suffered from "disciplinal insularity" (35) and from the curious practice in which most, if not all, peritrichous, gram-negative, rod-shaped

$\dagger$ Permanent address: Service des Entérobactéries, Institut Pasteur, F-75724 Paris, Cedex 15, France. bacteria that are associated with plants have been assigned to the genus Erwinia solely on the basis of their phytopathogenicity (40). These factors led us to undertake a survey on the relationships between plant and medical enterobacteria, in the course of which we found $E r$ winia proteamaculans to be identical with one biotype (C1c) of Serratia liquefaciens. After checking the authenticity of the only extant strain of the collection on which Paine and Stansfield based their description of $P$. proteamaculans $(\mathrm{ATCC} 19323=$ Dye $\mathrm{ZL} 1=\mathrm{ICPB}$ XP176 = NCPPB 245), we demonstrated the identity of this strain with $S$. liquefaciens biotype C1c (19) by comparison of biochemical reactions, polynucleotide sequence relatedness, and pathobiology upon inoculation of leaves of Protea cynaroides. Relevant nomenclatural changes are proposed.

\section{MATERIALS AND METHODS}

Bacterial strains. The histories of the bacterial strains studied are given in Table 1. Cultures of these strains were freeze-dried for long-term conservation (34) and were also maintained on semisolid yeast extract nutrient agar (19) during this study.

Bacteriological methods. Polygalacturonate degradation was studied using the pectate semisolid agar of Starr et al. (36). The caprylate-thallous agar medium, selective for members of the genus Serratia, has been described previously elsewhere (37). All other bacteriological tests were performed exactly as described by Grimont et al. (19). All tests were carried out at $30^{\circ} \mathrm{C}$, unless otherwise stated. 
TABLE 1. Bacterial strains studied ${ }^{a}$

\begin{tabular}{|c|c|c|c|}
\hline \multirow[b]{2}{*}{ Species } & \multicolumn{2}{|c|}{ Strain designation } & \multirow[b]{2}{*}{ Strain history $^{b}$} \\
\hline & ICPB & $\begin{array}{l}\text { Grimont et } \\
\text { al. (19) }\end{array}$ & \\
\hline Xanthomonas proteamaculans & XP176 & - & NCPPB $245 \leftarrow$ NCTC $394 \leftarrow$ S. G. Paine (29) \\
\hline Serratia liquefaciens .......... & 3989 & 508 & $\begin{array}{l}\text { CCM } 412 \leftarrow \text { CCEB } 309 ; \text { from insect, Saperda } \\
\text { carcharias }\end{array}$ \\
\hline S. liquefaciens & 3991 & 275 & $\begin{array}{l}\text { Le Minor 5-68 } \leftarrow \text { CDC } 6136-66 \text {; centrotype of } \\
\text { phenon C1 (19) }\end{array}$ \\
\hline S. liquefaciens & 3994 & 503 & $\begin{array}{l}\text { ATCC 14460; type strain of } S \text {. liquefaciens }(19, \\
\text { 33) }\end{array}$ \\
\hline S. plymuthica & 4002 & 510 & $\begin{array}{l}\text { CCM } 640 \leftarrow \text { ATCC } 183 \text {; type strain of S. ply- } \\
\text { muthica (19) }\end{array}$ \\
\hline S. marcescens & 4008 & 296 & $\begin{array}{l}\text { Brisou 5751; from water; centrotype of phenon } \\
\text { A (19) }\end{array}$ \\
\hline S. marinorubra & 4003 & 288 & $\begin{array}{l}\text { Sneath D119 } \leftarrow \text { ZoBell } 511 ; \text { type strain of } S \text {. } \\
\text { marinorubra (19) }\end{array}$ \\
\hline Enterobacter aerogenes & 2856 & A1 & $\begin{array}{l}\text { CIP } 60-86 \leftarrow \text { ATCC } 13048 \text {; neotype of } E . \text { aero- } \\
\text { genes }(20)\end{array}$ \\
\hline E. cloacae & 2857 & $\mathrm{Cl}$ & $\begin{array}{l}\text { CIP } 60-85 \leftarrow \text { ATCC } 13047 \text {; neotype of } E . \text { cloacae } \\
\quad(20)\end{array}$ \\
\hline Escherichia coli K-12 & 4023 & - & Strain J5 from N. Datta \\
\hline
\end{tabular}

${ }^{a}$ In addition to the above-mentioned Serratia strains, the following strains from the study of Grimont et al. (19) were used in plant inoculation experiments: Serratia liquefaciens 221,390 , and $509 ; S$. marcescens 5, 60, 81, 222, 246, 324, 481, and 1264; S. marinorubra 37, 377, and 530; S. plymuthica 34 and 392; Serratia sp. 38 and 1073.

${ }^{b}$ ATCC, American Type Culture Collection, Rockville, Md.; CCEB, Czechoslovak Collection of Entomogenous Bacteria, Prague; CCM, Czechoslovak Collection of Microorganisms, Brno; CDC, Center for Disease Control, Atlanta, Ga.; CIP, Collection de l'Institut Pasteur, Paris, France; ICPB, International Collection of Phytopathogenic Bacteria, Davis, Calif; NCPPB, National Collection of Plant Pathogenic Bacteria, Harpenden, England; NCTC, National Collection of Type Cultures, London, England.

DNA-DNA hybridization studies. The medium used in the labeling of deoxyribonucleic acid (DNA) with $\left[{ }^{3} \mathrm{H}\right.$ ]thymidine consisted of (per liter): $\mathrm{KH}_{2} \mathrm{PO}_{4}$, $2 \mathrm{~g} ; \mathrm{K}_{2} \mathrm{HPO}_{4}, 7 \mathrm{~g} ; \mathrm{MgSO}_{4} \cdot 7 \mathrm{H}_{2} \mathrm{O}, 0.1 \mathrm{~g} ;\left(\mathrm{NH}_{4}\right)_{2} \mathrm{SO}_{4}, 1 \mathrm{~g}$; glucose, $1 \mathrm{~g}$; Casamino Acids, $15 \mathrm{~g}$; and $\mathrm{NaCl}, 0.5 \mathrm{~g}$. Sixty milliliters of sterile medium in a Klett flask was inoculated with strain XP176. When the growth reached 40 Klett units, deoxyadenosine and $\left[{ }^{3} \mathrm{H}\right]$ thymidine (specific activity, $20 \mathrm{Ci} / \mathrm{mmol}$ ) were added at final concentrations in the medium of 250 and 8.0 $\mu \mathrm{g} / \mathrm{ml}$, respectively. The bacterial culture was harvested when it reached 240 Klett units. Radioactive DNA was extracted and purified by a published procedure (8). Extraction and purification of unlabeled DNAs and shearing of both labeled and unlabeled DNAs were done by the method of Brenner et al. (9), except that the purified DNAs were dialyzed against $0.042 \mathrm{M} \mathrm{NaCl}$ before shearing by sonic oscillation.

For hybridization experiments, the methods of Crosa et al. (12) and of Schiewe et al. (32) were followed with slight modifications. A mixture of $0.1 \mu \mathrm{g}$ of ${ }^{3} \mathrm{H}$-labeled DNA and $150 \mu \mathrm{g}$ of unlabeled DNA in $0.042 \mathrm{M} \mathrm{NaCl}$ (total volume, $0.75 \mathrm{ml}$ ) was denatured in a boiling-water bath for $4 \mathrm{~min}$ and immediately quenched in ice. The $\mathrm{NaCl}$ concentration was then adjusted to $0.42 \mathrm{M}$ by addition of $0.25 \mathrm{ml}$ of $1.554 \mathrm{M}$ $\mathrm{NaCl}$. This hybridization mixture was then incubated for $16 \mathrm{~h}$ in a $60^{\circ} \mathrm{C}$ water bath. Included as controls with each group of DNA reassociations were a homologous DNA reassociation (XP176/XP176), a sample containing only denatured labeled XP176 DNA, and a sample containing only native labeled XP176 DNA. After incubation, four $0.2-\mathrm{ml}$ samples were removed from each hybridization mixture and transferred to tubes containing $0.8 \mathrm{ml}$ of reaction mixture $(0.4 \mathrm{mM}$ $\mathrm{ZnSO}_{4}, 0.15 \mathrm{M} \mathrm{NaCl}, 0.03 \mathrm{M}$ sodium acetate buffer at pH 4.8, and $20 \mu \mathrm{g}$ of sheared and denatured calf thymus DNA per $\mathrm{ml}$ ). Two tubes from each reassociation mixture were each treated with $5.0 \mu \mathrm{l}(100 \mathrm{U})$ of $\mathrm{S} 1$ nuclease (Sigma Chemical Co., St. Louis, Mo.) for 20 min at $60^{\circ} \mathrm{C}$, and two tubes were treated identically but without the addition of the S1 enzyme. DNA duplexes remaining after this treatment were precipitated by the addition of $1.0 \mathrm{ml}$ of ice-cold $10 \%$ trichloroacetic acid and collected on glass-fiber filters (Whatman GF/F). Filters were washed with four $2.5-\mathrm{ml}$ volumes of ice-cold 5\% trichloroacetic acid and then with $2 \mathrm{ml}$ of acetone. The filters were dried and put into vials containing $5 \mathrm{ml}$ of scintillant $(4 \mathrm{~g}$ of Omnifluor per liter of toluene), and the radioactivity was measured in a Beckman model LS3145P liquid scintillation spectrometer. The degree of polynucleotide sequence homology was calculated by determining the ratio between the average counts in the nucleasetreated and nuclease-untreated samples. Results were then normalized to the homologous reaction.

Plant inoculations. Four pots of Protea cynaroides (vernacular name, King Protea) were obtained from Tropic World Inc. (Escondido, Calif.), and two others were obtained from Green Valley Nurseries 
(Escondido, Calif.). Overnight cultures of various bacteria in Trypticase soy broth (BBL Microbiology Systems) were deposited $(10 \mu \mathrm{l})$ on detached leaves of Protea cynaroides. Leaves were then lightly stabbed with a sterile platinum wire through the deposited drop of culture and were kept in a humid chamber at $30^{\circ} \mathrm{C}$. Inoculated leaves were examined for lesions every day for 14 days.

\section{RESULTS AND DISCUSSION}

Authenticity of culture XP176. Three means of checking the authenticity of strain XP176 were used: (i) tracing the history of this strain in the literature; (ii) comparing older descriptions of this strain with its present properties; (iii) checking the pathobiological activity of the strain for Protea cynaroides.

(i) History of strain ICPB XP176. Strain ICPB XP176 was received (as Xanthomonas proteamaculans) at the International Collection of Phytopathogenic Bacteria (ICPB; Davis, Calif.) in April 1961 from the National Collection of Plant Pathogenic Bacteria (NCPPB, Harpenden, England), where it is currently kept under the accession number NCPPB 245. The NCPPB had obtained the strain from the National Collection of Type Cultures (NCTC), London, England, as NCTC 394; however, the NCTC no longer lists this strain in its catalog. The NCTC had originally received the strain from S. G. Paine, who had isolated the organism in 1919 (29). A derivative of this strain is listed in the catalog (2) of the American Type Culture Collection (ATCC; Rockville, Md.) under the designation Erwinia proteamaculans ATCC 19323. The strain of this organism maintained in New Zealand (Dye ZL1; 13, 14) also derives from NCPPB 245. NCPPB 245 is a "cotype" according to Sneath and Skerman (33) and, to the best of our knowledge, it is the only remaining isolate of the collection on which Paine and Stansfield (29) based their description of $P$. proteamaculans.

(ii) Former descriptions of strain NCPPB 245 ( = ICPB XP176). From Paine and Stansfield's description (29), Pseudomonas proteamaculans is a gram-positive rod which is 0.8 to 1.6 by 0.6 to $0.8 \mu \mathrm{m}$ in size and motile by means of one to four flagella (most strains have a single, polar flagellum) and which produces wet, shining, dirty-white colonies (showing a faint yellow tinge) on agar. Gelatin is liquefied, nitrate is reduced, and acid and gas are produced from glucose, sucrose, and mannitol. Starch is only slightly hydrolyzed. From the drawing that accompanies this description, the bacteria actually seem to be peritrichous since some flagella are depicted as attached to the sides of the rod (13). Elliott (16) and earlier editions of Bergey's Man- ual of Determinative Bacteriology $(4,5)$ cited this description uncritically, under various generic names. In the seventh (1957) edition of Bergey's Manual (6), the description was corrected as follows: "Gram-positive (Paine and Stansfield). Gram-negative (Dowson, personal communication, August, 1953)." The descriptions given by Dye (of this same strain, under his designation ZL1) in 1966 (13) and in 1969 (14) closely resemble that of Enterobacter liquefaciens given by Edwards and Ewing (15): a Voges-Proskauer-positive, aerogenic enterobacterial species which fails to ferment rhamnose and lactose, which produces gelatinase and lipase, and which forms decarboxylases for lysine and ornithine but not for arginine. Our present study (see Table 2) shows that the characters of strain ICPB XP176 are the same as those of Dye's strain ZL1.

(iii) Pathobiological activity of culture XP176 on Protea cynaroides. Ten inoculations (out of 10 trials) of a broth culture of strain ICPB XP176, done by the procedure noted in Materials and Methods, on detached leaves of Protea cynaroides resulted in lesions within 2 to 3 days. The lesions were round, depressed, brown spots similar to those described and illustrated by Paine and Stansfield (29). However, when inoculations were made by placing a loopful of a nutrient agar culture on detached leaves and pricking the leaf through the applied culture, or when $0.01 \mathrm{ml}$ of a broth culture was injected with a syringe into undetached leaves, no lesion could be observed within 16 days. There is no evidence from the original report (29) that Pseudomonas proteamaculans was truly pathogenic to Protea cynaroides. The pathobiological reactions obtained in 1919 (29) and 1921 (28), and those described herein, are most probably "hypersensitive" reactions (22) rather than manifestations of a genuine phytopathogenicity. It should also be noted that, according to Dye (14), not a single case of bacterial spot disease on Protea cynaroides had been reported during the 50 -odd years after the original observations $(28,29)$.

Given the foregoing analysis, we conclude that strain ICPB XP176 is an authentic strain of Paine and Stansfield's $P$. proteamaculans. This same strain, under the designation NCPPB 245, has been listed (33) as the "cotype" of the synonymous species Erwinia proteamaculans. The Code (24) no longer recognizes the term "cotype"; hence, we designate strain ICPB XP176 as the type strain of $P$. proteamaculans.

Synonymy of $S$. liquefaciens with $P$. proteamaculans. Serratia liquefaciens and Pseudomonas proteamaculans are two names for the 
TABLE 2. Biochemical characteristics of strain ICPB XP176 of Xanthomonas proteamaculans compared with those of authentic Serratia liquefaciens strains (PADG 275, 503, and 508)

\begin{tabular}{|c|c|c|c|c|}
\hline \multirow{2}{*}{ Characteristic } & \multicolumn{4}{|c|}{ Reaction $^{a}$ of strain (biotype): } \\
\hline & $\begin{array}{c}\text { XP176 } \\
\text { (C1c) }\end{array}$ & $\begin{array}{c}508 \\
\text { (C1c) }\end{array}$ & $\begin{array}{c}275 \\
\text { (C1b) }\end{array}$ & $\begin{array}{c}503 \\
\text { (C1d) }\end{array}$ \\
\hline \multicolumn{5}{|l|}{ Carbon source utilization: } \\
\hline 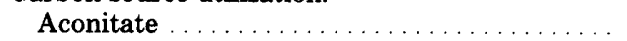 & + & + & 0 & 0 \\
\hline Adonitol $\ldots \ldots \ldots \ldots \ldots \ldots \ldots \ldots$ & 0 & 0 & 0 & 0 \\
\hline L-Arabinose $\ldots \ldots \ldots \ldots \ldots \ldots \ldots$ & + & + & + & + \\
\hline D-Arabitol $\ldots \ldots \ldots \ldots \ldots$ & 0 & 0 & 0 & 0 \\
\hline$\ldots \ldots \ldots \ldots$ & 0 & 0 & 0 & + \\
\hline$\ldots \ldots \ldots \ldots \ldots \ldots$ & 0 & 0 & 0 & 0 \\
\hline DL-Carnitine $\ldots \ldots \ldots \ldots \ldots \ldots \ldots$ & 0 & 0 & 0 & 0 \\
\hline Cellobiose $\ldots \ldots \ldots \ldots \ldots \ldots$ & + & + & + & + \\
\hline$\ldots \ldots \ldots \ldots \ldots$ & 0 & 0 & 0 & 0 \\
\hline Histamine . . . . . . . . . & 0 & 0 & 0 & 0 \\
\hline 3-Hydroxybenzoate $\ldots \ldots \ldots \ldots \ldots \ldots$ & 0 & 0 & 0 & 0 \\
\hline 4-Hydroxybenzoate $\ldots \ldots \ldots \ldots \ldots$ & 0 & 0 & 0 & + \\
\hline Lactose $\ldots \ldots \ldots \ldots$ & 0 & 0 & 0 & $(+)$ \\
\hline Melibiose $\ldots \ldots \ldots$ & + & + & + & + \\
\hline$\alpha$-Methylglucoside $\ldots \ldots \ldots \ldots \ldots \ldots \ldots$ & + & + & + & $(+)$ \\
\hline Mucate $\ldots \ldots \ldots \ldots \ldots \ldots \ldots$ & 0 & 0 & 0 & 0 \\
\hline Nicotinate $\ldots \ldots \ldots \ldots \ldots \ldots$ & + & + & $(+)$ & $(+)$ \\
\hline L-Ornithine $\ldots \ldots \ldots \ldots$ & $?$ & $?$ & $(+)$ & 0 \\
\hline$\ldots \ldots \ldots \ldots$ & 0 & 0 & 0 & 0 \\
\hline$\ldots \ldots \ldots \ldots \ldots$ & 0 & 0 & 0 & 0 \\
\hline Sorbitol $\ldots \ldots \ldots \ldots$ & + & + & + & + \\
\hline Sucrose $\ldots \ldots \ldots \ldots \ldots \ldots \ldots$ & + & + & + & + \\
\hline D-Tartrate & 0 & 0 & 0 & 0 \\
\hline Trigonelline $\ldots \ldots \ldots \ldots \ldots$ & 0 & 0 & 0 & 0 \\
\hline Growth on caprylate-thallous agar (37) $\ldots \ldots$ & + & + & + & + \\
\hline  & + & + & + & + \\
\hline$\beta$-Galactosidase $(\mathrm{ONPG})^{b} \ldots \ldots \ldots \ldots \ldots$ & + & + & + & + \\
\hline 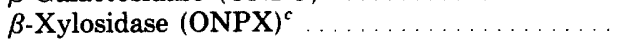 & 0 & 0 & 0 & $\mathbf{w}$ \\
\hline Tetrathionate reduction $\ldots \ldots \ldots \ldots \ldots \ldots$ & + & + & + & + \\
\hline Lysine decarboxylase $\ldots \ldots \ldots \ldots \ldots \ldots \ldots$ & + & + & + & + \\
\hline Ornithine decarboxylase $\ldots \ldots \ldots \ldots \ldots \ldots \ldots$ & + & + & + & + \\
\hline Arginine dihydrolase $\ldots \ldots \ldots \ldots \ldots \ldots$ & 0 & 0 & 0 & + \\
\hline Tryptophan deaminase $\ldots \ldots \ldots \ldots$ & 0 & 0 & 0 & 0 \\
\hline Urea hydrolysis $\ldots \ldots \ldots \ldots \ldots \ldots \ldots$ & 0 & 0 & 0 & 0 \\
\hline Malonate $\ldots \ldots \ldots \ldots$ & 0 & 0 & 0 & 0 \\
\hline $\mathrm{H}_{2} \mathrm{~S}$ (peptone water) & 0 & 0 & 0 & 0 \\
\hline $\mathrm{H}_{2} \mathrm{~S}$ (peptone water + cysteine) & + & + & + & + \\
\hline Indole production $\ldots \ldots \ldots \ldots$ & 0 & 0 & 0 & 0 \\
\hline Simmons citrate & + & + & + & + \\
\hline Growth at $4^{\circ} \mathrm{C}$. & + & + & + & + \\
\hline DNA hydrolysis & + & + & + & + \\
\hline Tween 80 hydrolysis & + & + & + & + \\
\hline Gelatin hydrolysis . & + & + & + & + \\
\hline Chitin hydrolysis. & 0 & 0 & 0 & 0 \\
\hline Polygalacturonate degradation (36) $\ldots$ & 0 & 0 & 0 & 0 \\
\hline Glucose fermentation ( $\mathrm{O} / \mathrm{F}$ medium) & + & + & + & + \\
\hline Gas from glucose $\ldots \ldots \ldots \ldots \ldots \ldots$ & + & + & + & + \\
\hline
\end{tabular}

${ }^{a}$ Symbols: + , with carbon sources, growth within 4 days or, in other tests, positive within 1 day; $(+)$, with carbon sources, growth within 5 to 14 days or, in other tests, positive within 2 to 8 days; w, weak reaction; ?, doubtful reaction at the end of the observation time; ND, not determined.

${ }^{b}$ ONPG, $o$-Nitrophenyl- $\beta$-D-galactopyranoside.

${ }^{c}$ ONPX, o-Nitrophenyl- $\beta$-D-xylopyranoside.

${ }^{d}$ Moles percent guanine plus cytosine.

${ }^{e}$ From buoyant density; determined by M. Mandel.

${ }^{f}$ From melting point (19). 
TABLE 2-Continued

\begin{tabular}{|c|c|c|c|c|}
\hline \multirow[b]{2}{*}{ Characteristic } & \multicolumn{4}{|c|}{ Reaction $^{a}$ of strain (biotype): } \\
\hline & $\begin{array}{c}\text { XP176 } \\
\text { (C1c) }\end{array}$ & $\begin{array}{c}508 \\
(\mathrm{Clc})\end{array}$ & $\begin{array}{c}275 \\
(\mathrm{C} 1 \mathrm{~b})\end{array}$ & $\begin{array}{c}503 \\
(\mathrm{Cld}) \\
\end{array}$ \\
\hline Voges-Proskauer test $(30) \ldots \ldots \ldots \ldots \ldots$ & + & + & + & $?$ \\
\hline Methyl red test & 0 & 0 & 0 & 0 \\
\hline \multicolumn{5}{|l|}{ Acid from: } \\
\hline Arabinose & + & + & + & + \\
\hline$\ldots \ldots \ldots \ldots \ldots$ & 0 & 0 & 0 & 0 \\
\hline$\ldots \ldots \ldots \ldots$ & + & + & + & + \\
\hline$\ldots \ldots \ldots \ldots \ldots \ldots$ & + & + & + & + \\
\hline Lactose $\ldots \ldots \ldots \ldots \ldots \ldots \ldots \ldots \ldots$ & 0 & 0 & 0 & 0 \\
\hline 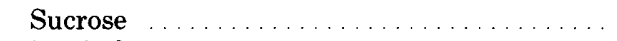 & + & + & + & + \\
\hline Inositol & $(+)$ & $(+)$ & $(+)$ & $(+)$ \\
\hline Raffinose ... & + & + & + & + \\
\hline DNA base composition ${ }^{d}$ & $54.1^{e}$ & ND & $53.8^{f}$ & $53.4^{e}$ \\
\hline
\end{tabular}

same species. This opinion is based on three types of evidence derived from study of the type strains of these species: (i) phenotypic characters; (ii) DNA-DNA hybridization trials; and (iii) pathobiological response.

(i) Phenotypic characters of $P$. proteamaculans and S. liquefaciens. The biochemical characteristics of Pseudomonas proteamaculans ICPB XP176 are given in Table 2, along with those of three authentic strains of Serratia liquefaciens. With respect to the 57 tests used, there is $100 \%$ similarity between strains ICPB XP176 and PADG 508 (ICPB 3989; S. liquefaciens biotype $\mathrm{Clc}$ ). This allows the identification of strain ICPB XP176 as a member of biotype $\mathrm{Clc}$ of $\mathrm{S}$. liquefaciens. Growth on aconitate as the sole carbon source is the only reliable test for differentiating $S$. liquefaciens biotype $\mathrm{Clc}$ from biotype C1a or C1b (19). In practice, only two tests-growth on benzoate and decarboxylation of arginine-allow the differentiation of $S$. liquefaciens biotype C1d from biotypes C1a, C1b, C1c (19). Biotype C1d includes the type strain (ATCC $14460=$ ICPB $3994=$ PADG 503), included in our comparative examination (see Tables 1 to 3), of $S$. liquefaciens (19). On the basis of biochemical criteria, the type strain of $P$. proteamaculans and that of $S$. liquefaciens belong to two different biotypes $(\mathrm{Cl}$ c and $\mathrm{Cld}$, respectively) of the same species.

(ii) Polynucleotide sequence relatedness of $P$. proteamaculans and $S$. liquefaciens. The DNA-DNA hybridization data obtained in this study (Table 3) support the identification of strain ICPB XP176 as a member of biotype C1c of Serratia liquefaciens. The question of whether S. liquefaciens as presently constituted contains more than one DNA hybridization group needs further study, especially since Steigerwalt et al. (39) found $S$. liquefaciens to be a rather heterogeneous species with respect to polynucleotide sequence relatedness. The hydroxyapatite method used by Brenner's group $(7,39)$ differs from the S1 nuclease method we used; our procedure may have given (Table 3 ) a lower apparent percentage relatedness between ICPB XP176 and PADG 275 or PADG 503 than if the relatedness had been determined by the hydroxyapatite procedure. "Calibration" comparisons of the two methods as applied to Serratia DNAs remain to be made.

(iii) Pathobiological identity. Inoculation of Protea cynaroides leaves with 23 strains representative of all Serratia species (19) gave results that were not significantly different from that given by strain ICPB XP176 of Pseudo. monas proteamaculans: all strains elicited identical pathobiological reactions on detached leaves in 9 of 10 experiments; in all cases, the reactions were identical with those reported earlier $(28,29)$ for $P$. proteamaculans. This finding comes as no surprise since Lakso and Starr (23) have shown that enterobacteria (including Serratia spp.) from humans could cause plants to produce "hypersensitive" reactions of the same sort observed here and earlier $(28,29)$ with $P$. proteamaculans.

Generic assignment. We recommend that Pseudomonas proteamaculans be transferred to the genus Serratia Bizio. As a fermentative, peritrichous organism, the bacterium isolated from Protea cannot remain associated with the genus Pseudomonas. These same traits plus the ability to grow on a minimal-glucose medium without growth factors, a DNA base composition (about 53 to $54 \mathrm{~mol} \%$ guanine plus cytosine) much below the 63 to $71 \mathrm{~mol} \%$ guanine plus cytosine typical of Xanthomonas spp. (27), and no known ability to produce brominated, arylpolyene xanthomonadin pigments (38) exclude this species also from the genus Xanthomonas. This conclusion was also reached by Dye (13) in 
TABLE 3. Reassociation of DNAs from various enterobacteria at $60^{\circ} \mathrm{C}$ with ${ }^{3} \mathrm{H}$-labeled DNA from Xanthomonas proteamaculans ICPB XP176

\begin{tabular}{|c|c|}
\hline Strain & Relatedness ${ }^{a}$ to XP176 $\left[{ }^{3} \mathrm{H}\right] \mathrm{DNA}(\%)$ \\
\hline 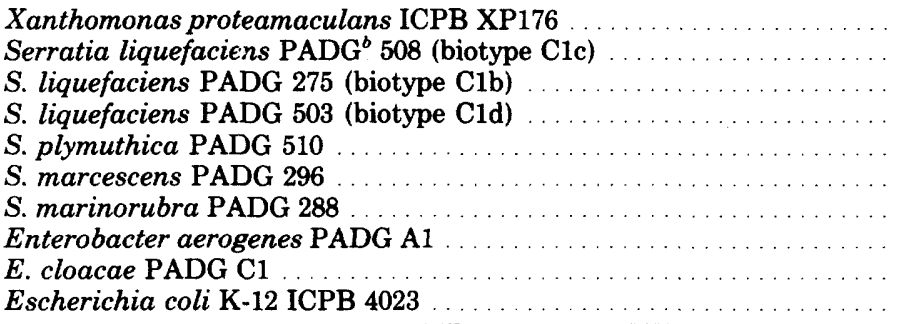 & $\begin{aligned} & 100 \\
& 105 \pm 9.9^{c} \\
& 69 \pm 6.4 \\
& 57 \pm 5.7 \\
& 50 \pm 4.9 \\
& 41 \pm 1.4 \\
& 39 \pm 1.4 \\
& 16 \pm 4.2 \\
& 15 \pm 11.9 \\
& 14 \pm 2.1\end{aligned}$ \\
\hline
\end{tabular}

${ }^{a}$ Reassociation determined by the $\mathrm{S} 1$ nuclease procedure described in the text.

${ }^{b}$ Strain designations as used by Grimont et al. (19); see footnote $b$ of Table 1 for other designations.

${ }^{c}$ Standard deviation.

1966, when he transferred this species to the genus Erwinia. The genus Erwinia Winslow et al. 1917 (40) was erected as a repository for all plant-associated, peritrichous, gram-negative rods-an artificial, ecologically based grouping which by no means mirrors significant taxonomic relationships (35). Moustardier et al. (26) and others (35) have suggested that many of the present members of the genus Erwinia might be distributed among other genera within the family Enterobacteriaceae-an arrangement which seems to be more rational than the present practice. Both Dye (14) and Lelliott (25) recommended exclusion of Erwinia proteamaculans from the genus Erwinia and discussed its placement in the genus Enterobacter. In fact, Dye (14) stated: "Erwinia proteamaculans [Dye ZL1 = ICPB XP176] is another organism having cultural and biochemical characters closely resembling those described for Enterobacter"; consequently, this author proposed (14) the name Enterobacter proteamaculans (Paine and Stansfield 1919) Dye 1969 for the organism here under consideration. Imbs et al. (21) included the very same Erwinia proteamaculans strain in a recent numerical taxonomic survey of the genus Erwinia, in which the API 50 microdeterminative system provided the data base. In that study, Erwinia proteamaculans (Dye ZL1 $=$ ICPB XP176) clustered with seven clinical isolates labeled Enterobacter liquefaciens. Unfortunately, their study did not include the type strain of Enterobacter liquefaciens, no nomenclatural proposal was made, and no comparative description of Enterobacter liquefaciens and Erwinia proteamaculans was given.

Our study shows indisputably that the two nomenspecies Enterobacter proteamaculans and Enterobacter liquefaciens correspond to the same taxospecies. The species originally described in 1931 by Grimes and Hennerty (18) under the name Aerobacter liquefaciens was renamed Enterobacter liquefaciens by Ewing (17) and, in turn, was transferred to the genus Serratia by Bascomb et al. (3); the latter nomenclatural change has been supported by studies on numerical taxonomy (19) and polynucleotide sequence relatedness (39). In the context of DNA-DNA homology, the paper by Steigerwalt et al. (39) shows that DNA from Serratia liquefaciens is much more closely related to DNA from Serratia marcescens (the type species of the genus Serratia Bizio) than to DNA from either Erwinia amylovora (the type species of the genus Erwinia Winslow et al.) or Enterobacter cloacae (the type species of the genus Enterobacter Hormaeche and Edwards). Table 2 indicates that DNA from Erwinia proteamaculans is identical to DNA from $S$. liquefaciens biotype C1c and, moreover, that it is more closely related to $S$. marcescens DNA than to either Enterobacter cloacae or Enterobacter aerogenes DNA.

Furthermore, the present study shows that the organism originally named Pseudomonas proteamaculans is best placed in the genus Serratia because it is identical in all respects (Tables 2 and 3) to $S$. liquefaciens biotype C1c. Because of the principle of priority (24), we are thus faced with two alternative nomenclatural positions: either (i) to recommend replacement of the specific epithet "liquefaciens" in the name Serratia liquefaciens (Grimes and Hennerty 1931) Bascomb et al. 1971 by the specific epithet "proteamaculans"; or (ii) to request the Judicial Commission of the International Committee on Systematic Bacteriology to allow conservation (24) of the well-known name Serratia liquefaciens. We favor the former approach. Conservation of a name is often requested when an earlier synonym is poorly known and is not represented by an authentic culture (24). In the 
case of Pseudomonas proteamaculans, although the name is probably unknown to most medical bacteriologists, plant bacteriologists have included this species in several taxonomic studies $(13,14,21,31)$. The species Pseudomonas proteamaculans (with different generic names) was listed in Elliott's Manual of Bacterial Plant Pathogens (16) and in several editions of Bergey's Manual (4-6, 10); moreover, the name appears in the first draft of the Approved List of Bacterial Names (1) as Erwinia proteamaculans (Paine and Stansfield 1919) Dye 1966. A single authentic strain of this organism is extant (ATCC 19323 = Dye ZL1 = ICPB XP176 $=$ NCPPB 245). The reason that the synonymy of $S$. liquefaciens and $E$. proteamaculans was not recognized earlier probably stems from the disciplinal insularity (35) among bacteriologists: medical and plant bacteriologists rarely co-mingle; they often use different methods; and they have for years built and followed quite different

Proposed changes in nomenclature. Based on the foregoing arguments, we propose the following nomenclatural alterations. (i) The species described by Paine and Stansfield (29) under the name Pseudomonas proteamaculans is to be transferred to the genus Serratia. The correct name for this species is Serratia proteamaculans (Paine and Stansfield 1919) comb. nov. (ii) ICPB XP176 ( = ATCC $19323=$ Dye ZL1 = NCPPB 245) is here proposed to be the type strain of Serratia proteamaculans. (iii) Serratia liquefaciens (Grimes and Hennerty 1931) Bascomb et al. 1971 is a junior subjective synonym of Serratia proteamaculans (Paine and Stansfield 1919) comb. nov. (iv) The four presently authenticated species of the genus Serratia are Serratia marcescens Bizio 1823, Serratia marinorubra ZoBell and Upham 1944, Serratia plymuthica (Lehmann and Neumann 1896) Breed et al. 1948, and Serratia proteamaculans (Paine and Stansfield 1919) comb. nov.

\section{ACKNOWLEDGMENTS}

This research was supported by Public Health Service research grant AI-08426 from the National Institute of Allergy and Infectious Diseases. During the period this study was effected, P.A.D. Grimont was the recipient of a Bourse de Recherche du Ministère des Affaires Etrangères (France).

We thank Manley Mandel for the determinations of DNA base compositions.

\section{REPRINT REQUESTS}

Address reprint requests to: Dr. M. P. Starr, Department of Bacteriology, University of California, Davis, CA 95616.

\section{LITERATURE CITED}

1. Ad-Hoc Committee of the Judicial Commission of the ICSB. 1976. First draft. Approved list of bacterial names. Int. J. Syst. Bacteriol. 26:563-599.
2. American Type Culture Collection. 1974. Catalogue of strains, 11th ed. American Type Culture Collection, Rockville, Md.

3. Bascomb, S., S. P. Lapage, W. R. Willcox, and M. A. Curtis. 1971. Numerical classification of the tribe Klebsielleae. J. Gen. Microbiol, 66:279-295.

4. Bergey, D. H., F. C. Harrison, R. S. Breed, B. W. Hammer, and F. M. Huntoon. 1930. Bergey's manual of determinative bacteriology, 3rd ed. The Williams and Wilkins Co., Baltimore.

5. Breed, R. S., E. G. D. Murray, and A. P. Hitchens. 1948. Bergey's manual of determinative bacteriology, 6th ed. The Williams and Wilkins Co., Baltimore.

6. Breed, R. S., E. G. D. Murray, and N. R. Smith. 1957. Bergey's manual of determinative bacteriology, 7th ed. The Williams and Wilkins Co., Baltimore.

7. Brenner, D. J. 1973. Deoxyribonucleic acid reassociation in the taxonomy of enteric bacteria. Int. J. Syst. Bacteriol. 23:298-307.

8. Brenner, D. J., G. R. Fanning, K. E. Johnson, R. V. Citarella, and S. Falkow. 1969. Polynucleotide sequence relationships among members of the Enterobacteriaceae. J. Bacteriol. 98:637-650.

9. Brenner, D. J., G. R. Fanning, F. J. Skerman, and S. Falkow. 1972. Polynucleotide sequence divergence among strains of Escherichia coli and closely related organisms. J. Bacteriol. 108:953-965.

10. Buchanan, R. E., and N. E. Gibbons (ed.). 1974. Bergey's manual of determinative bacteriology, 8 th ed. The Williams and Wilkins Co., Baltimore.

11. Burkholder, W. H. 1948. Genus I. Erwinia Winslow et al., p. 463-478. In R. S. Breed, E. G. D. Murray, and A. P. Hitchens (ed.), Bergey's manual of determinative bacteriology, 6th ed. The Williams and Wilkins Co., Baltimore.

12. Crosa, J. H., D. J. Brenner, and S. Falkow. 1973. Use of a single-strand specific nuclease for analysis of bacterial and plasmid deoxyribonucleic acid homo- and heteroduplexes. J. Bacteriol. 115:904-911.

13. Dye, D. W. 1966. A comparative study of some atypical "xanthomonads." N.Z. J. Sci. 9:843-854.

14. Dye, D. W. 1969. A taxonomic study of the genus Erwinia. IV. "Atypical" erwinias. N.Z. J. Sci. 12:833-838.

15. Edwards; P. R., and W. H. Ewing. 1972. Identification of Enterobacteriaceae, 3rd ed. Burgess Publishing Co., Minneapolis.

16. Elliott, C. 1930. Manual of bacterial plant pathogens. The Williams and Wilkins Co., Baltimore.

17. Ewing, W. H. 1963. An outline of nomenclature for the family Enterobacteriaceae. Int. Bull. Bacteriol. Nomencl. Taxon. 13:95-110.

18. Grimes, M., and A. J. Hennerty. 1931. A study of bacteria belonging to the subgenus Aerobacter. Sci. Proc. Roy. Dublin Soc. (N. S.) 20:89-97.

19. Grimont, P. A. D., F. Grimont, H. L. C. Dulong de Rosnay, and P. H. A. Sneath. 1977. Taxonomy of the genus Serratia. J. Gen. Microbiol. 98:39-66.

20. Hormaeche, E., and P. R. Edwards. 1960. Proposal for the rejection of the generic name Cloaca Castellani and Chalmers and proposal of Enterobacter as a generic name with designation of type species and of its type culture. Int. Bull. Bacteriol. Nomencl. Taxon. 10:75-76.

21. Imbs, M. A., R. Bene, T. Girard, C. Goulon, and P. Dixneuf. 1977. Taxonomie numérique des bactéries du genre Erwinia. Microbia 3:3-34.

22. Klement, Z., and R. N. Goodman. 1967. The hypersensitive reaction to infection by bacterial plant pathogens. Annu. Rev. Phytopathol, 5:17-44.

23. Lakso, J. U., and M. P. Starr. 1970. Comparative injuriousness to plants of Erwinia and other enterobacteria from plants and animals. J. Appl. Bacteriol. 33:692-707.

24. Lapage, S. P., P. H. A. Sneath, E. F. Lessel, V. B. D. Skerman, H. P. R. Seeliger, and W. A. Clark (ed.). 
1975. International code of nomenclature of bacteria. American Society for Microbiology, Washington, D.C.

25. Lelliott, R. A. 1974. Genus XII. Erwinia Winslow, Broadhurst, Buchanan, Krumwiede, Rogers, and Smith 1920, 209, p. 332-339. In R. E. Buchanan and N. E. Gibbons (ed.), Bergey's manual of determinative bacteriology, 8 th ed. The Williams and Wilkins Co., Baltimore.

26. Moustardier, G., J. Brisou, J. Saout, and J.-P. Erhardt. 1961. Les Erwinia: discussion taxonomique. Bull. Assoc. Diplomes Microbiol. Fac. Pharm. Nancy 82:3-12.

27. Murata, N., and M. P. Starr. 1973. A concept of the genus Xanthomonas and its species in the light of segmental homology of deoxyribonucleic acids. Phytopathol. Z. 77:285-323.

28. Paine, S. G., and E. M. Berridge. 1921. Studies in bacteriosis. V. Further investigation of a suggested bacteriolytic action in Protea cynaroides affected with the leaf-spot disease. Ann. Appl. Biol. 8:20-26.

29. Paine, S. G., and H. Stansfield. 1919. Studies in bacteriosis. III. A bacterial leaf spot disease of Protea cynaroides, exhibiting a host reaction of possibly bacteriolytic nature. Ann. App. Biol. 6:27-39.

30. Richard, C. 1972. Méthode rapide pour l'étude des réactions de rouge de méthyle et Voges-Proskauer. Ann. Inst. Pasteur (Paris) 122:979-986.

31. St. John-Brooks, R., K. Nain, and M. Rhodes. 1925. The investigation of phytopathogenic bacteria by serological and biochemical methods. J. Pathol. Bacteriol. 28:203-209.

32. Schiewe, M. H., J. H. Crosa, and E. J. Ordal. 1977. Deoxyribonucleic acid relationships among marine vibrios pathogenic to fish. Can. J. Microbiol. 23:954-958.

33. Sneath, P. H. A., and V. B. D. Skerman. 1966. A list of type and reference strains of bacteria. Int. J. Syst. Bacteriol. 16:1-113.

34. Starr, M. P. 1970. Curatorial problems peculiar to an international collection of phytopathogenic bacteria, $p$. 69-71. In H. lizuka and T. Hasegawa (ed.), Culture collections of microorganisms. University of Tokyo Press, Tokyo.

35. Starr, M. P., and A. K. Chatterjee. 1972. The genus Erwinia: enterobacteria pathogenic to plants and animals. Annu. Rev. Microbiol. 26:389-426.

36. Starr, M. P., A. K. Chatterjee, P. B. Starr, and G. E. Buchanan. 1977. Enzymatic degradation of polygalacturonic acid by Yersinia and Klebsiella species in relation to clinical laboratory procedures. J. Clin. Microbiol. 6:379-386.

37. Starr, M. P., P. A. D. Grimont, F. Grimont, and P. B. Starr. 1976. Caprylate-thallous agar medium for selectively isolating Serratia and its utility in the clinical laboratory. J. Clin. Microbiol. 4:270-276.

38. Starr, M. P., C. L. Jenkins, L. B. Bussey, and A. G. Andrewes. 1977. Chemotaxonomic significance of the xanthomonadins, novel brominated aryl-polyene pigments produced by bacteria of the genus Xanthomonas. Arch. Microbiol. 113:1-9.

39. Steigerwalt, A. G., G. R. Fanning, M. A. Fife-Asbury, and D. J. Brenner. 1976. DNA relatedness among specis of Enterobacter and Serratia. Can. J. Microbiol. 22:121-137.

40. Winslow, C. E. A., J. Broadhurst, R. E. Buchanan, C. Krumwiede, Jr., L. A. Rogers, and G. H. Smith. 1917. The families and genera of the bacteria. Preliminary report of the Committee of the Society of American Bacteriologists on Characterization and Classification of Bacterial Types. J. Bacteriol. 2:505-566. 